\title{
PENGUKURAN KINERJA TEKNOLOGI INFORMASI PERUSAHAAN ABC MENGGUNAKAN IT BALANCED SCORECARD DAN BTRIPPLEE FRAMEWORK
}

\author{
Handoko $^{1}$, Catherine ${ }^{2}$, Riche $^{3}$ \\ 1,2,3Program Studi Sistem Informasi, STMIK Mikroskil, Medan, Indonesia \\ Email: ${ }^{1}$ handoko.wu@ mikroskil.ac.id, ${ }^{2}$ catherine.yang@mikroskil.ac.id, ${ }^{3}$ riche@ mikroskil.ac.id
}

\begin{abstract}
Abstrak
Teknologi informasi (TI) yang diterapkan perusahaan dapat membantu peningkatan efektivitas dan efisiensi yang berkaitan dengan aktivitas operasional perusahaannya. Pengukuran implementasi TI dilakukan pada perusahaan ABC yang bergerak di bidang layanan jasa teknologi informasi disetiap proses bisnis. Untuk mengintegrasikan proses bisnis dengan implementasi teknologi informasi saat ini, sangat dibutuhkan pengukuran TI melalui konsep Balanced Scorecard (BSC) dalam perusahaan ABC. Dalam perusahaan $\mathrm{ABC}$, pengukuran kinerja TI sangat penting dilakukan untuk mengetahui sejauh mana tahap perkembangan bisnis perysahaan sehingga mampu mencapai visi dan misi organisasi dalam jangka waktu pendek maupun panjang. Dari segi efektivitas dan efisiensi, perusahaan $\mathrm{ABC}$ memiliki teknologi informasi dan memprioritaskan pemenuhan strategi bisnis maupun strategi TI. Sejumlah transaksi-transaksi bisnis yang dilakukan setiap harinya dapat mengalami risiko kegagalan implementasi TI yang berdampak terhadap kemajuan perusahaan. Adapun metode yang digunakan untuk pengukuran maturity TI dalam perusahaan ABC adalah IT BSC yang dikombinasikan dengan BTripleE Framework. Dari hasil analisis yang dilakukan, terdapat berbagai temuan yang terkait dengan risiko dan kegagalan implementasi TI dalam perusahaan sehingga didapatkan evaluasi TI yang digunakan sebagai tindakan responsif terhadap implementasi TI tersebut. Setelah itu, hasil deskripsi bentuk BTripleE Framework diterapkan dalam penggunaan IT BSC yang mempertimbangkan 4 perspektif melalui perhitungan Key Performance Indicator (KPI), meliputi corporate contribution, future orientation, operational excellence, dan customer orientation.
\end{abstract}

Kata kunci: Pengukuran Kinerja TI, IT Balanced Scorecard, BtrippleE Framework, Key Performance Indicator

\begin{abstract}
Information technology (IT) applied by the company can help increase the effectiveness and efficiency associated with the company's operational activities. Measurement of IT implementation is carried out on ABC companies engaged in information technology services in every business process. To integrate business processes with the current implementation of information technology, IT measurements are needed through the concept of the Balanced Scorecard (BSC) in ABC companies. In ABC companies, IT performance measurement is very important to know the extent of the company's business development stage so that it can achieve the organization's vision and mission in the short and long term. In terms of effectiveness and efficiency, ABC companies have information technology and prioritize meeting business and IT strategies. A number of business transactions carried out every day can run the risk of failure of IT implementation which impacts on the company's progress. The method used to measure IT maturity in ABC company is IT BSC combined with BTripleE Framework. From the results of the analysis conducted, there are various findings related to the risk and failure of IT implementation in the company so that an evaluation of IT is obtained which is used as a responsive action towards the IT implementation. After that, the description of the BTripleE Framework form is applied in the use of IT BSC that considers 4 perspectives through the calculation of Key Performance Indicators (KPI), including corporate contribution, future orientation, operational excellence, and customer orientation.
\end{abstract}

Keywords: IT Performance Measurement, IT Balanced Scorecard, BtrippleE Framework, Key Performance Indicator

\section{PENDAHULUAN}

Teknologi sudah menjadi faktor pendukung perusahaan untuk mencapai tujuan bisnisnya, namun apabila teknologi tidak digunakan sesuai dengan kebutuhan perusahaan maka teknologi yang sudah diterapkan justru akan berdampak kepada pengeluaran biaya yang tidak menghasilkan keuntungan [1]. Teknologi informasi (TI) yang diterapkan oleh perusahaan sudah menjadi suatu nilai saing yang harus dikelola dengan baik oleh perusahaan [1]. Oleh karena itu perlu dilakukan suatu metode pengukuran efektivitas dan efisiensi teknologi informasi pada perusahaan yang menerapkan teknologi informasi, baik bagi perusahaan yang baru menerapkan atau bagi perusahaan yang ingin meningkatkannya [2]. Perusahaan ABC merupakan salah satu perusahaan yang bergerak di bidang layanan jasa teknologi informasi. Dalam proses bisnisnya perusahaan memberikan layanan berupa aplikasi IoT Automotive Industries, khususnya Fleet Monitoring Platform. Salah satu aktifitas untuk mempertahankan dan meningkatkan kinerja teknologi informasi yang sudah dijalankan perusahaan adalah melakukan upgrade dari teknologi informasi yang sebelumnya dikelola sendiri menjadi cloud infrastructure. Hal ini dilakukan dengan tujuan agar perusahaan dapat meningkatkan performa aplikasi dikarenakan jumlah transaksi sudah meningkat dan memutuskan untuk menggunakan layanan Oustource Cloud Infrastructur Microsoft Azure. Dengan begini perusahaan juga bisa berfokus kepada pengembangan aplikasi dan pengelolaan end user support. Tools yang dapat digunakan untuk IT Balance Scorecard dapat membantu perusahaan untuk melihat bagaimana kontribusi teknologi informasi ini dapat menjadi keunggulan kompetitif bagi perusahaan [2]. Kombinasi IT Balanced Scorecard dan BtrippleE Framework digunakan untuk menentukan seberapa baik kontribusi dari peningkatan infrastruktur yang sudah dilakukan perusahaan.

\section{TINJAUAN TEORITIS}




\subsection{IT Balanced Scorecard}

Balanced Scorecard (BSC) tradisional mulai diadopsi untuk digunakan dalam Departemen Teknologi Informasi perusahaan. Perspektif yang digunakan pada Balanced Scorecard tradisional harus diubah dan disesuaikan agar dapat digunakan dan diimplementasi sehingga dapat sesuai dengan kebutuhan Departemen Teknologi Informasi. Departemen Teknologi Informasi berperan sebagai penyedia layanan bagi pegawai internal. Pendekatan balance scorecard yang merujuk ke kekuatan perusahaan yang dimiliki bersifat holistik yang berskala luas dan terdapat keselarasan yang tinggi antara proses komunikasi dan aliran informasi strategi perusahaan secara keseluruhan [3]. Adapun beberapa perubahan dan penyesuaian yang dilakukan terlihat seperti pada gambar berikut [2]:

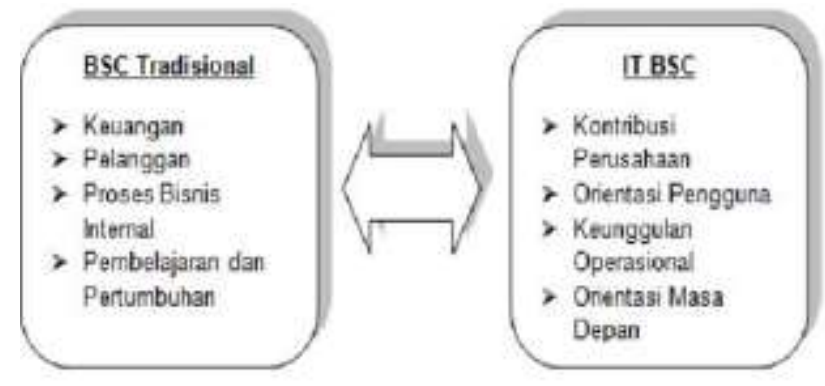

Gambar 1. Penyesuaian Balanced Scorecard Tradisional dengan IT Balanced Scorecard

Berdasarkan gambar di atas, maka Perspektif IT Balanced Scorecard dapat dijabarkan sebagai berikut [2]:

1. User Orientation, Perspektif Orientasi Pengguna merupakan perspektif menggunakan cara pandang pengguna bisnis (pelanggan) dan lebih jauh lagi pelanggan dari unit bisnis dalam mengevaluasi kinerja penerapan teknologi informasi. Dalam perspektif ini, perusahaan mengidentifikasi pelanggan dan segmen pasar yang akan dimasuki. Dengan perspektif ini, maka perusahaan dapat menyelaraskan berbagai ukuran pelanggan, seperti: kepuasan, loyalitas, retensi, akuisisi, profitabilitas dengan pelanggan sendiri atau segmen pasar.

2. Business Contribution, Perspektif kontribusi bisnis menggunakan pandangan dari manajemen eksekutif, para direktur, dan shareholder dalam mengevaluasi kinerja teknologi informasi. Pada perspektif ini, evaluasi teknologi informasi dapat dibagi menjadi dua yaitu:

a. Jangka pendek berupa evaluasi finansial

b. Jangka panjang yang berorientasi pada proyek dan fungsi teknologi informasi itu sendiri.

3. Operational Exellence, Perspektif Keunggulan Operasional menggunakan efektivitas dan efisiensi dari prosesproses teknologi informasi yang dinilai oleh pihak manajemen untuk mengukur kinerja teknologi informasi.

4. Future Orientation, Perspektif orientasi masa depan ini menggunakan pandangan departemen teknologi informasi itu sendiri terhadap tantangan di masa depan untuk menilai kinerja teknologi informasi. Perspektif ini berfokus pada kemampuan organisasi dalam menghadapi tantangan di masa depan. Pihak manajerial harus mampu melihat ke masa depan dan membuat langkah-langkah penanganan yang diperlukan.

Selain itu, IT BSC ini dapat dikaitkan dengan pencapaian objektif bisnis sebagai sasaran utama dengan mempertimbangkan rencana strategis TI [4]. Didalam penggunaan balanced scorecard ini membantu pihak manajemen perusahaan untuk menentukan hasil-hasil atau keputusan bisnis yang lebih strategis dan memanfaatkan peluang dan hubungan sebab akibat yang terdapat dalam perusahaan [5]. Pencapaian sasaran bisnis yang dapat didukung dengan adanya penilaian KPI (Key Performance Indicators) melalui proses benchmarking [6]. Dengan adanya perhitungan dalam KPI, perusahaan dapat melakukan perhitungan estimasi dan aktual kinerja organisasi, trace, dan perbedaan terhadap tingkat maturity teknologi informasi dan hasil produk yang dikembangkan melalui perkembangan atau trend teknologi saat ini [7]. Strategi bisnis yang diprioritaskan juga mempertimbangkan stakeholder scorecard sebagai faktor pendorong untuk memberikan nilai tambah bagi perusahaan secara optimal [8] Perusahaan juga mengutamakan kebutuhan setiap karyawan yang terlibat untuk pengembangan produk perusahaan melalui rekomandasi pengukuran terhadap implementasi TI [8] [3]. Hal ini menghasilkan kinerja yang lebih baik terhadap implementasi teknologi informasi yang lebih baik. Nilai-nilai bisnis yang efektif dan efisien dapat diukur dari berbagai aspek, meliputi [4]:

1. Operational services scorecard berkaitan dengan pengukuran aktivitas operasional perusahaan secara keseluruhan.

2. Governance services scorecard berkaitan dengan pengukuran tata kelola perusahaan yang telah memenuhi standar kebijakan perusahaan yang lebih baik.

3. Development services scorecard berkaitan dengan proses pengembangan perusahaan yang semakin berkembang dan mempertimbangkan struktur pembuatan produk.

\subsection{Konsep BTripleE}

Sebuah kerangka kerja yang menghubungkan perencanaan teknologi informasi dengan penilaian teknologi informasi pada tingkatan yang ditentukan disebut sebagai kerangka BtripleE. 


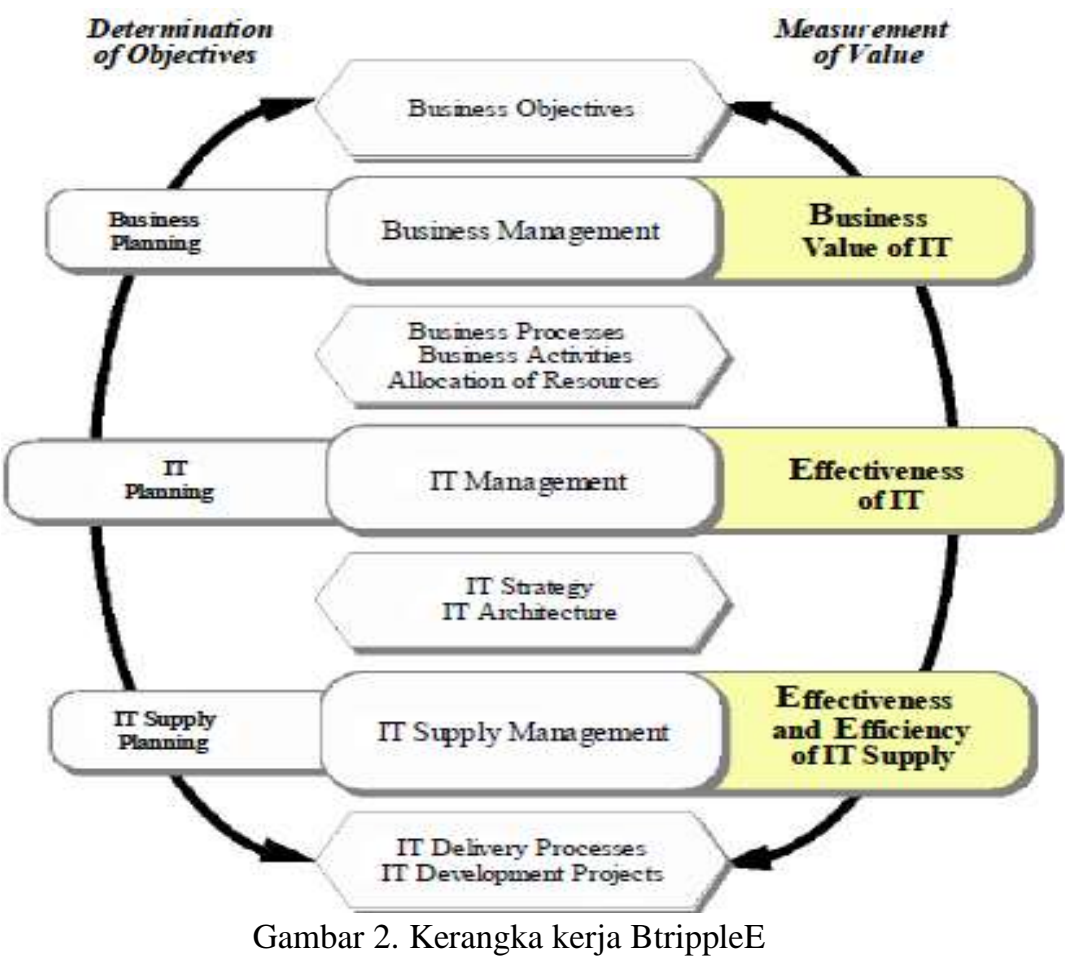

Karena tingkat perencanaan dan nilai saling terkait, baik ke bawah maupun ke atas, setiap kerangka perencanaan dan penilaian teknologi informasi harus mendukung penyelarasan top-down dan inisiatif perencanaan bottom-up. Panah dua arah pada gambar di atas mencerminkan aspek-aspek ini. Kerangka BtripleE telah dikembangkan untuk memenuhi kebutuhan para manajer untuk mengetahui bagaimana mengukur nilai atau value dari teknologi informasi yang multi dimensi dan komprehensif, yang menyediakan satu cakupan untuk organisasi dalam pencarian nilai atau value dari teknologi informasi mereka, yang dibedakan dalam tiga tingkatan. Sebuah keunikan dari BTripleE melihat nilai value dari teknologi informasi pada sebuah organisasi adalah dengan melihat sejauh mana impact dari sudut pandang nilai ekonomis terhadap penerapan teknologi informasi pada organisasi tersebut.

1. Poin pertama yang menjadi titik bahasan BtripleE adalah Business Value of IT, dalam hal ini nilai bisnis yang dimaksudkan adalah bagaimana nilai (dari sudut pandang manfaat ekonomis) dari teknologi informasi pada sebuah organisasi. Kita mengacu pada Effectiveness (sejauh mana infrastuktur teknologi informasi mampu memberikan manfaat pada sudut pandang organisasi) dan Efficiency (sejauh mana biaya investasi yang dikeluarkan untuk infrastruktur teknologi informasi mampu memberikan throughput (capacity) yang maksimal sesuai dengan permintaan dari Bisnis sendiri.

a. Efektivitas dapat juga merupakan kesesuaian antara visi, misi, dan objektif jangka panjang terhadap kesesuaian strategis dan tata kelola teknologi informasi sehingga keadaan yang harmonis bisa terbentuk. Dinamisasi visi, misi, dan objektif bukan tidak mugkin terjadi namun hal ini tetap merupakan bagian yang perlu diperhitungkan dalam penyusunan strategi yang tentunya berpengaruh pada perencanaan TI.

b. Efisiensi dalam kaitan maksimalisasi dari biaya yang sudah dikeluarkan sehingga throughput maksimal dapat diperoleh dan bisnis dapat merasakan nilai yang terbaik dari investasi yang sudah dikeluarkan. Pada beberapa kasus implementasi, biasa faktor resiko juga merupakan bagian yang diperhitungkan sehingga kecenderungan tidak hanya kepada seberapa besar manfaat yang dapat dirasakan dari sebuah investasi TI, namun pada resiko jangka panjang yang mungkin dapat terjadi.

Business Value of IT berfokus kepada seberapa besar manfaat yang dirasakan dari adanya penerapan teknologi informasi pada sebuah organisasi, terukur dari sudut pandang efektifitas dan efisiensi. Semua ukuran ukuran nilai bisnis, menyangkut dengan hubungan antara biaya-biaya teknologi informasi dan kontribusinya terhadap peningkatan kinerja organisasi, yang dapat diukur dalam 3 dimensi:

a. Financial Performance. Diukur dengan indikator kinerja keuangan suatu organisasi. Profitability: diperoleh dari produktivitas dan efisiensi yang menurunkan biaya operasional; Revenue: diukur dengan presentasi pendapatan organisasi, dibagi indikator tingkatan pengeluaran teknologi informasi yang benar; Productivity: hubungan antara output yang dihasilkan dengan input yang digunakan untuk menghasilkan output tersebut dari suatu sistem.

b. Business Performance. Kinerja bisnis dapat diukur dengan indikator kinerja non keuangan sebagai komplemen dan kombinasi dengan ukuran kinerja keuangan. Ukuran kinerja non keuangan banyak digunakan bisnis untuk pengendalian internal dan untuk menghubungkan biaya-biaya teknologi informasi 
dengan peningkatan kinerja bisnis, misalnya keunggulan bersaing, penjualan produk-produk baru, waktu pengembangan produk baru, kepuasan pelanggan dll.

c. Strategic Performance. Pengukuran nilai bisnis dari teknologi informasi dengan menghubungkan biayabiaya teknologi informasi dan kinerja strategis dari organisasi, yang hanya dapat diukur dengan total biaya dan seberapa organisasi dapat merealisasikan Critical Success Factor (CSF), aktivitas-aktivitas terkritis yang memberikan kontribusi pada keberhasilan bisnis paling besar yang pada akhirnya jika aktivitas kritis dapat dilaksanakan dengan baik maka dapat dijamin bahwa kinerja kompetitif dapat berhasil bagi organisasi.

2. Poin selanjutnya sebagai bagian dari BtripleE ini menyorot tentang efektivitas dari teknologi informasi yang sedikit berbeda. Efektivitas ini lebih menyorot terhadap bagaimana bisnis unit lainnya melihat teknologi informasi dalam cakupan prosesnya namun tetap pada kemampuan teknologi informasi dalam menyediakan semua fungsi yang dibutuhkan dengan ketersediaan biaya yang ada. Departemen fungsional yang ada, misalnya marketing, procurement, sales, dll melihat kesesuaian kebutuhan antara ketersediaan resource sehingga pekerjaan dapat berjalan secara lebih baik dalam 3 hal batasan yaitu kecepatan (speed), kapasitas (capacity), dan pengurangan interaksi manusia (less human interaction). Biaya yang dikeluarkan untuk ini bisa terus disesuaikan hingga dirasakan dari pertambahan speed, capacity, dan less human interaction yang tidak terlalu signifikan dalam penambahan per satuan mata uang. Ini dapat berarti tingkat investasi telah mencapai titik optimal dan belum diperlukan kembali pertambahan dari investasi teknologi informasi.

3. Poin ketiga dalam BtrippleE adalah Effectiveness IT Supply dan Efficiency IT Supply. Kedua kata kunci ini memberikan penekanan yang berbeda. Setiap organisasi memiliki apa yang menjadi tujuan yang tercermin dari visi, cara pencapaian yang tercermin dari misi, serta objektif yang merupakan kumpulan target yang selaras dengan misi jangka panjang perusahaan. Meski terdapat dua kata kunci pada poin ini, namun keduanya menyoroti hal yang sama, yaitu IT Supply. IT Supply ini bisa diartikan sebagai pengeluaran yang dikeluarkan dalam operasional teknologi informasi. Effectiveness melihat seberapa besar tingkat kesesuaian strategi teknologi informasi (rinciannya berupa teknologi informasi Expenditures) untuk dikaitkan dengan tujuan perusahaan jangka panjang. Sementara efficiency mengacu pada minimalnya biaya yang dikeluarkan untuk mengejar target tersebut sehingga ini semua bisa mudah dimonitor dengan membandingkan pengeluaran dan peningkatan bisnis terkait teknologi informasi.

\section{METODE PENELITIAN}

Penelitian ini menggunakan kombinasi antara teknologi informasi Balanced Scorecard yang merupakan hasil modifikasi dari Balanced Scorecard konvensional yang diintegrasikan dengan BtrippleE Framework untuk melakukan penilaian kinerja penerapan Teknologi Informasi dalam sebuah perusahaan. Dalam hal ini, aspek-aspek dalam IT BSC untuk pengukuran knerja organisasi, meliputi:

1. Corporate Contribution

Dalam perusahaan ABC dilakukan identifikasi ketersediaan TI yang mampu mendukung aktivitas operasional bisnis dan membantu pengembangan finansial organisasi.

2. Future Orientation

Pada perspektif ini dilakukan pengukuran TI yang berkaitan dengan inovasi baru dan pengembangan produk sebagai hasil dukungan TI dalam perusahan ABC.

3. Operational Excellence

Perspektif ini menggunakan pengukuran seberapa efektif dan efisien penerapan teknologi informasi berdasarkan waktu operasi TI.

4. Customer Orientation

Perspektif ini menggambarkan pengelolaan informasi yang didistribusikan ke pelanggan sehingga nilai pelanggan dapat menambahkan pencapaian strategi bisnis maupun strategi TI dalam perusahaan.

\section{HASIL DAN PEMBAHASAN}

\subsection{BTripleE: Effectiveness and Efficiency of teknologi informasi Supply}

Aktivitas penelitian ini berfokus pada layanan infrastruktur teknologi informasi yang digunakan oleh perusahaan, maka kami mengacu kepada scorecard teknologi informasi Infrastructure Management dengan perspektif internal, customer, dan learning.

Tabel 1. Hasil Analisis BTrippleE

\begin{tabular}{ll}
\hline \multicolumn{1}{c}{ Temuan } & \multicolumn{1}{c}{ Hasil Evaluasi } \\
\hline $\begin{array}{l}\text { Pernah ditemukan kegagalan sistem dalam } 2 \\
\text { bulan terakhir sebanyak 1 kali }\end{array}$ & $\begin{array}{l}\text { Hal ini disebabkan karena gangguan jaringan nasional, } \\
\text { vendor sudah memberikan antisipasi dengan menggunakan } \\
\text { backup server sehingga layanan tetap bisa digunakan. }\end{array}$
\end{tabular}


IT Expert yang bertugas untuk mengawasi infrastruktur teknologi informasi hanya berjumlah 1 orang

Terdapat banyak fitur yang disediakan vendor cloud infrastructure namun masih belum digunakan secara maksimal

Saat masa transisi ke cloud, pelanggan yang sudah menggunakan aplikasi merasakan dampaknya seperti akses laporan yang lebih stabil dan akses halaman web lebih responsif
1 orang yang bertugas sudah dilengkapi dengan prosedur penanganan yang dapat dilakukan secara remote sehingga memudahkan monitoring penggunaan $\mathrm{CPU}$ dan jaringan

IT Manager bersama dengan CTO sedang melakukan Focus Group Discussion bersama dengan tim expert yang disediakan vendor terkait proses pengolahan basis data. Apakah ada fitur yang tepat untuk hal ini.

Hal ini dikarenakan perpindahan infrastrukur teknologi berbasis cloud karena sebelumnya server yang digunakan untuk aplikasi sudah berumur 3 tahun dan data transaksinya sudah melebihi kapasitas

\subsection{IT Balanced Scorecard}

Berdasarkan observasi yang sudah dilakukan menggunakan metode BtripleE pada layer Effectiveness and Efficiency of IT Supply. IT Balance Scorecard pada perusahaan yang mengacu kepada 4 perspektif dapat dibuatkan model key performance indicator-nya (KPI) sebagai berikut:

\begin{tabular}{lll}
\hline \multicolumn{1}{c}{ Perspektif } & \multicolumn{1}{c}{ KPI } & \multicolumn{1}{c}{ Target } \\
\hline Corporate Contribution & Availability & Uptime Sistem Online mencapai 99,9\% \\
Future Orientation & Innovation & Major Updates atau fitur baru aplikasi mencapai 3x / tahun \\
Operational Excellence & Resolution Time & Keluhan pelanggan dapat mendapat resolusi dalam waktu 1 x \\
& & 24 jam \\
Customer Orientation & Usability & Waktu yang dibutuhkan untuk mendapatkan informasi atau \\
& & laporan harus dibawah 1 menit \\
\hline
\end{tabular}

Dengan menggunakan layanan cloud infrastructure perusahaan bisa berfokus kepada pengembangan aplikasi dan pengelolaan end user support. Namun dibutuhkan suatu strategi inisiatif untuk mencapai target dari indikator yang sudah ditentukan. Maka dari itu dibuatkan model inisiatif berdasarkan indikator perusahaan. Adapun model inisiatif tersebut adalah sebagai berikut:

Tabel 3. Model Inisiatif

\begin{tabular}{|c|c|c|c|}
\hline Perspektif & KPI & Target & Inisiatif \\
\hline Corporate Contribution & Availability & $\begin{array}{lrl}\text { Uptime } & \text { Sistem } & \text { Online } \\
\text { mencapai } 99,9 \% & \end{array}$ & $\begin{array}{l}\text { Menerapkan alert system yang } \\
\text { dapat membantu tim memonitor } \\
\text { apabila terjadi gangguan pada } \\
\text { cloud ifrastructure }\end{array}$ \\
\hline Future Orientation & Innovation & $\begin{array}{l}\text { Major Updates atau fitur } \\
\text { baru aplikasi mencapai } 3 \mathrm{x} \\
\text { / tahun }\end{array}$ & $\begin{array}{l}\text { Memanfaatkan fitur dari layanan } \\
\text { cloud yang sudah disediakan } \\
\text { yang dapat mendukung } \\
\text { pengembangan aplikasi }\end{array}$ \\
\hline Operational Excellence & Resolution Time & $\begin{array}{l}\text { Keluhan pelanggan dapat } \\
\text { mendapat resolusi dalam } \\
\text { waktu } 1 \times 24 \text { jam }\end{array}$ & $\begin{array}{l}\text { Membuat support center yang } \\
\text { didukung oleh tim teknis yang } \\
\text { dapat membantu pelanggan untuk } \\
\text { menyelesaikan masalah. }\end{array}$ \\
\hline Customer Orientation & Usability & $\begin{array}{l}\text { Waktu yang dibutuhkan } \\
\text { untuk mendapatkan } \\
\text { informasi atau laporan } \\
\text { harus dibawah } 1 \text { menit }\end{array}$ & $\begin{array}{l}\text { Memonitor penggunaan server } \\
\text { dan membuat prosedur } \\
\text { penanganan apabila terjadi } \\
\text { peningkatan penggunaan } \mathrm{CPU} \\
\text { dan jaringan }\end{array}$ \\
\hline
\end{tabular}

\section{KESIMPULAN}

Berdasarkan dari hasil observasi yang sudah dilakukan, perusahaan ABC sudah menerapkan teknologi informasi yang dapat membantu layanan jasa teknologi informasi yang digunakan pelanggannya. Namun perusahaan belum memaksimalkan sumber daya yang dimiliki untuk menjalankan inisiatif strategi untuk mendukung pencapaian indikator sesuai dengan perspektif IT Balance Scorecard.

Dari hasil analisis dibentuknya suatu model inisiatif berdasarkan indikator yang sudah ditentukan. Dengan penyesuaian keselarasan antara strategi bisnis dengan strategi TI maka perusahaan ABC terbantu untuk memaksimalkan pemanfaatan infrastruktur teknologi informasi yang sudah diterapkan oleh perusahaan. Berdasarkan masing-masing perspektif IT BSC dan BTripleE Framework, perusahaan ABC melakukan pengukuran KPI secara 
detail sehingga penerapan TI dapat dimaksimalkan atau dioptimalisasikan secara berkelanjutan. Hal ini memicu faktor-faktor keberhasilan pemenuhan adanya strategi organisasi yang terus di-update baik dalam jangka waktu pendek maupun panjang.

\section{REFERENCES}

[1] T. Koller, M. Goedhart and D. Wessels, Valuation: measuring and managing the value of companies, vol. 499, John Wiley and Sons, 2010.

[2] I. Van der zee and T. M. Han, Measuring the value of information technology, London: IGI Global, 2002.

[3] J. Taylor and C. Baines, "Performance Management in UK Unniversities: Implementing the Balanced Scorecard," Journal of Higher Education Policy and Management, vol. 34, no. 2, pp. 111-124, 2012.

[4] W. V. Grembergen, R. Saull and S. D. Haes, "Linking the IT Balanced Scorecard to the Business Objectives at a Major Canadian Financial Group," Journal of Information Technology Case and Application Research, vol. 5, no. 1, pp. 23-50, 2014.

[5] W. Sewell, R. B. Mason and P. Venter, "Socio-Economic Developmental Strategies as Retail Performance Indicators: A Balanced Scorecard Apporach," Development Southern Africa, pp. 1-19, 2017.

[6] F. Y. Y. Ling and S. Peh, "Key Performance Indicators for Measuring Contractors' Performance," Architectural Science Review, vol. 48, no. 1, pp. 357-365, 2011.

[7] Y.-M. Tu, H.-N. Chen and S.-H. Chang, "The Design of Key Performance Indicators on Technology Development of A Water Foundry," Journal of the Chinese Institute of Industrial Engineers, vol. 27, no. 5, pp. 351-362, 2010.

[8] H. Sundin, M. Granlund and D. A. Brown, "Balancing Multiple Competing Objectives with a Balanced Scorecard," European Accounting Review, vol. 19, no. 2, pp. 203-246, 2010. 